\title{
Body image perception in scholars of a school in the Brazilian north region
}

\author{
Leila A. Evangelista ${ }^{1}$, Denise Aerts², Gehysa G. Alves ${ }^{3}$, Lilian Palazzo ${ }^{4}$, Sheila Câmara ${ }^{5}$, \\ Maria Helena Jacob ${ }^{6}$
}

\begin{abstract}
:
Introduction: In the adolescence period, an individual experiences biopsychosocial changes and dissatisfaction with body image is quite prevalent at this stage.

Objective: To investigate the prevalence of body image dissatisfaction and its association with demographic and psychosocial factors, sexual maturity, nutritional condition and lifestyle.

Methods: Cross-sectional study with a sample representing 831 eighth grade students from Porto Velho, Rondônia, Brazil, stratified into clusters. The data were obtained by questionnaires - the Body Shape Questionnaire and Global School-based Student Health Survey - and anthropometry. The associations of interest were tested in a multivariate analysis with Cox regression adjusted for cross-sectional studies.

Results: The prevalence of body image dissatisfaction was 22 per cent. The outcome was significantly more prevalent among girls (PR: 4.69; Cl: 95\%: 3.09 - 7.12), young Caucasians (PR: 1.32 ; Cl: $95 \%$ : $1.02-1.72$ ), those who used tobacco (RP: 1.53 ; Cl: $95 \%$ : $1.12-2.09$ ), who were overweight or obese (PR: 2.77; Cl: 95\%: 2.18 - 3.51), and who reported feelings of sadness (PR: 1.35; Cl: 95\%: $1.05-1.73$ ) and loneliness (PR: 1.66; Cl: 95\%: $1.30-2.11$ ). The students with lower weight were more satisfied with their image.
\end{abstract}

Conclusion: The results point to the need for parents, educators and health professionals to act jointly in developing actions that reinforce the positive qualities of youth, especially in girls. Encouraging physical activity and healthy habits can promote overall health, improving satisfaction with body image.

Keywords: adolescent; adolescent health; body image; body dissatisfaction.

\section{INTRODUCTION}

Body image conceives all the ways of the human experience and conceptualize your own body, enabling its positioning in the existential and personal context ${ }^{1}$. The perceived body image is linked to an understanding of wider concepts of image and body, and to the subjectivity of the person who is marked by their complex physical, psy- chological, environmental and behavioural experiences².

Contemporary society worships the body as the source of identity. Sociocultural factors and the large range of media increasingly influence the search for an ideal of physical beauty, closely related to happiness, eventually causing discontent and distancing the person from their real body ${ }^{3}$.

Adolescence is a particularly significant stage for healthy emotional development, due to the inherent

1 Professora Mestre do ILES/ULBRA (Universidade Luterana do Brasil) Porto Velho - Rua João Goulart, 666 Bairro Mato Grosso · CEP 78.950-415 - Porto Velho/RO.

2 Professora Doutora do Programa de Pós-Graduação em Saúde Coletiva da ULBRA/Canoas - RS. Av. Farroupilha, 8001 - Bairro São José · CEP 92425-900 - Canoas/RS.

3 Professora Doutora do Programa de Pós-Graduação em Saúde Coletiva da ULBRA/Canoas - RS. Av. Farroupilha, 8001 - Bairro São José · CEP 92425-900 - Canoas/RS.

4 Professora Doutora da ULBRA/Canoas - RS. Av. Farroupilha, 8001 · Bairro São José CEP 92425-900 · Canoas/RS.

5 Professora Doutora da Universidade Federal de Ciências da Saúde de Porto Alegre (UFCSPA) - Rua Sarmento Leite, 245 - Porto Alegre/RS

6 Professora Doutora do Programa de Pós-Graduação em Saúde Coletiva da ULBRA/Canoas - RS. Av. Farroupilha, 8001 · Bairro São José · CEP 92425-900 · Canoas/RS.

Corresponding author: Maria Helena Jacob -e-mail: mhvmjacob@hotmail.com

Suggested citation: Evangelista LA, Aerts D, Alves GG, Palazzo L, Câmara S, Jacob MH. Percepção da imagem corporal em escolares do norte do Brasil. J Hum Growth Dev. 2016;26(3): 385-392. DOI: http://dx.doi.org/10.7322/jhgd.122917

Manuscript submitted 21 May 2016, accepted for publication 14 Sep 2016. 
changes of puberty. The young person believes that, to be accepted, their body must conform to established 'standards' and so often becomes dissatisfied, leading to distortions in their body image ${ }^{4}$. Adolescents, regardless of gender, are concerned with their body image ${ }^{5}$, but there is a higher prevalence of dissatisfaction with body image in female students ${ }^{3,6}$. Sociocultural pressures lead females to an ideal of extreme thinness and males to an athletic and muscular torso. These are images that constantly reach young people through various media - commercials, films, television ${ }^{7,8}$.

In search of the ideal appearance, young people can adopt damaging behaviours and habits, reaching more serious situations such as anorexia or bulimia, or use of licit and illicit substances ${ }^{9}$. Adolescence is a critical time for these behaviours, especially the use of alcohol (the most used drug by adolescents), tobacco and marijuana, which is one of the biggest concerns in terms of public health ${ }^{10}$.

Body image covers physiological, cognitive, emotional and social processes, and it may result in determining lifestyles and psychosocial characteristics. Because of this, the present study aimed to investigate the prevalence of concern over body image in adolescents in Porto Velho, Rondônia, Brazil, and its association with demographic and psychosocial factors, sexual maturity, nutritional condition and lifestyle. The results may support public policies on health and education to promote school health and improve quality of life in a poorly studied region.

\section{METHODS}

This research was part of a larger study entitled 'Health education of the public school system in the northern region of Brazil'. The satellite project took place in Porto Velho, Rondônia, Brazil, a city on the right bank of the Madeira River, a River Amazon tributary. The city has a poor periphery, with little order and infrastructure; it has an estimated population of 494,013 people and a population density of 12.57 inhabitants $/ \mathrm{km}^{2}$ (IBGE, 2014) ${ }^{11}$.

The target population of this cross-sectional study consisted of 4,667 students from the eighth grade of elementary public schools, enrolled in 2010 in 47 schools, in morning and afternoon shifts. To calculate the sample size, this number was taken as a starting point, estimating the prevalence of the outcome at 50 per cent, a maximum tolerated error of \pm four per cent and a 95 per cent confidence interval. Thus, we calculated a sample of 532 schoolchildren. To correct possible bias design, we applied a design effect of 1.5 , plus 25 per cent of subjects to replace possible losses, totalling 994 students. The study used cluster sampling (classes), stratified by administrative region (poles) of the municipality. The number of students was drawn proportional to those at each pole in relation to the total enrolled at eight years in all poles. In total, there were 33 randomly selected groups, excluding pregnant women and adolescents with health problems that prevented anthropometry.

The population number was randomly selected as 1,075 , having 244 losses (22.7 per cent), resulting in a final sample of 831 adolescents. Losses occurred due to a refusal to participate in the study, non-delivery of the informed consent (WIC), school change or contact impossibility after three attempts. As the sample was calculated with a margin of 25 per cent, those losses could be absorbed without damage to the study. This number of subjects has 80 per cent power to detect higher interest associations, equal to 1.5 .

Four data collection instruments were used along with a form for recording anthropometric data per class, which also served as the control of the research instruments and delivery of CI. This worksheet contained the student's name, weight, height, gender, self-reported skin colour, date of birth and evaluation. The skin colour variable was categorized after collection as white or non-white.

The first instrument was a self-administered questionnaire known as the Body Shape Questionnaire (BSQ), validated for use in adolescents ${ }^{12}$. In national polls, it is the most used and easy to understand instrument. There are 34 items that assess concern with weight gain, low self-esteem due to physical appearance, desire for weight loss and worry (dissatisfaction) with body image. With the added points, the outcome analysed was binary concern/dissatisfaction with body image: no $(<81$ points) and yes ( $\geq 81$ points).

The second instrument was the self-assessment form of sexual maturation derived from Tanner ${ }^{13}$, which evaluates the perception of sexual maturity through images that indicate five different stages of development of secondary sexual characteristics for both genders. Stage 1 refers to infant characteristics; stage 2 is the first manifestations of sexual maturity or onset of puberty; stage 3 corresponds to changes in body composition or the growth spurt; in stage 4 there is a slowdown in growth; and stage 5 indicates the completion of the process of sexual maturation. For the analyses, sexual maturity was put into three categories, covering stages 1 and 2; stage 3; and stages 4 and 5.

The third instrument was a self-administered questionnaire on physical activity and economic situation, based, respectively, on the International Physical Activity Questionnaire (IPAQ) ${ }^{14}$, which classifies as physically active a youth who reports 300 minutes or more of weekly activity, and the Brazilian Association of Research Companies questionnaire $(\mathrm{ABEP})^{15}$, which brings together people in economic classes A (high), B, C, D and E (low). Due to the small number of subjects in the extreme categories, classes were regrouped into A and B, C, and D; there is no case of class E.

The fourth instrument was a self-administered questionnaire on various factors and outcomes under study, based on the Global School-based Student Health Survey (GSHS $)^{16}$, proposed by the WHO to assess the exposure to health risk behaviours in adolescents, validated for the Portuguese language.

In terms of anthropometry, weight was measured with G-Tech digital scales, capacity $150 \mathrm{~kg}$ and precision $50 \mathrm{~g}$, and height with WISO anthropometric fiberglass tape with pinpoint accuracy. Young people were measured with minimal clothing (underwear) and barefoot, in private, with routinely calibrated and technical equipment recommended by the $\mathrm{WHO}^{17}$. Body Mass Index (BMI) was assessed using the National Council of Health 
Sciences (NCHS) curves, according to gender and age in months ${ }^{18}$, where the relevant classifications were underweight ( $<5$ th percentile), normal weight (between percentiles 5 and 85$)$ and overweight/obesity ( $>85$ th percentile).

Data were collected by an academic in physical education of the university ILES/ULBRA-PVH and a Master's in Public Health ULBRA-RS, properly trained for this purpose. The collection was carried out in schools in the student class shift.

For the investigation of associations of interest, univariate and multivariate analyses were performed using Cox regression, modified for cross-sectional studies. Dissatisfaction with body image was used as a dichotomous dependent variable and the others as associated factors. Cox regression was applied using a hierarchical model in three stages; the criterion for participation in the stage was a significance level of $<0.20$. In the first stage of the multivariate analysis, along with the outcome, the variables entered into the model were gender, age, skin colour and economic status. In the second stage, the following variables were added: physical activity, use of tobacco in life, alcohol and drugs, nutritional condition and sexual maturation. In the third stage, the variables of first sexual intercourse, suicidal thoughts, feelings of sadness and feelings of loneliness were introduced. The final model included variables with a significance level $<0.05$, originally introduced in the previous steps.

The students were contacted for invitation and explanation of the research. They received a consent form for parents or guardians and guidance on the signature thereof, authorizing participation. This research was approved by the Research Ethics Committee of the Lutheran University of Brazil (No. 2009-251H) and authorized by SEDUC-RO, being secured to the ethical aspects interviewed, as required by Resolution 196/9619. The research was conducted according to the standards required by the Declaration of Helsinki ${ }^{20}$.

\section{RESULTS}

\section{Characteristics of adolescents studied}

The study population comprised 831 public school pupils from Porto Velho, Rondônia, Brazil, of whom 56.7 per cent (471) were female. In all, 648 children (78 per cent) were classified as not concerned with body image, 117 (14 per cent) were slightly concerned, 44 (5.3 per cent) were moderately concerned and 22 (2.7 per cent) were extremely concerned about their image.

The ages ranged between 12 and 19 years, with a mean of 14.34 years $(\mathrm{SD}= \pm 1.01)$; the highest concentration was in the range of 14 to 15 years $(70.7$ per cent). Most teens (74 per cent) declared the mselves nonwhite and were classified in economic class A and B (53.2 per cent) and class C (43.9 per cent). Only 24 belonged to class D and none to class E.

Regarding lifestyle, 52.8 per cent were classified as physically active ( $\geq 300$ minutes weekly) and the prevalence of use of tobacco in life, alcohol and drugs was, respectively, 17.2 per cent, 49.6 per cent and 5.3 per cent. The eutrophic scholars accounted for 60.6 per cent of the sample; 20.6 were low weight and $18.8 \%$ per cent overweight/obese.

The students' perception of their sexual maturity indicated that 82.6 per cent were in stages 4 and 5 and only 3.3 per cent in stages 1 and 2 . As for sexually activity, 74.5 per cent of young people mentioned not having started. In terms of psychosocial characteristics, 17 per cent, 28.5 per cent and 29 per cent reported suicidal thoughts, feelings of sadness and feelings of loneliness, respectively.

\section{Factors associated with preoccupation with body image}

In the first stage of the multivariate analysis, of the four variables that entered the model, only gender and skin colour were associated with the outcome. Girls reported 4.69 times more concern than boys, and whites had 32 per cent more concern than their reference pairs (Table 1).

In the second stage, of the six variables, only use of tobacco and nutritional condition were significantly associated with the outcome. Young people with low birth weight showed 67 per cent less concern than eutrophic. In contrast, overweight/ obesity prevalence showed nearly three times (PR: 2.77) more concern than the reference category. Similar to these, the students who tried smoking reported 53 per cent more concern than those who had never experimented (Table 1).

In the third stage, despite all the variables having been associated with the outcome in the univariate analysis, only young people who reported feelings of sadness and loneliness had, respectively, 35 per cent and 66 per cent more concern over body image than their reference counterparts. Thus, the final model included the variables gender, skin colour, use of tobacco, nutritional status, feelings of sadness and loneliness (Table 1).

\section{DISCUSSION}

The media influences today's society and sociocultural factors associated with particular body image shape the success of affective relationships and good economic condition. Because of this, we must be alert to the influence of strict standards of beauty on the self-image of adolescents. In this study, a high percentage ( 78 per cent) of young people were found not to be concerned about their body image but, among the dissatisfied, most were female. Such female dissatisfaction may be associated with the fact that the maturation of girls is earlier than boys. Other studies, in contrast, have shown that male adolescents showed greater dissatisfaction with their body image ${ }^{21,22}$. Comparing the data from the National School of Health (PeNSE) 2009 and 2012, Malta and colleagues ${ }^{10}$ found no significant difference in body image perception between the genders in both editions of the study. This controversial framework encourages further research on body image and the numerous variables related to it in this important phase.

In Gravataí, Rio Grande do Sul, Brazille ${ }^{23}$, the prevalence of satisfaction among adolescent students was 75.1 per cent, quite similar to that in Porto Velho. However, among girls, it was only 59.8 per cent. In this study, the 
Table 1: Population distribution of the variables of interest and univariate and multivariate Cox regression for concern with body image among adolescents from public schools, Porto Velho, Rondônia, 2010

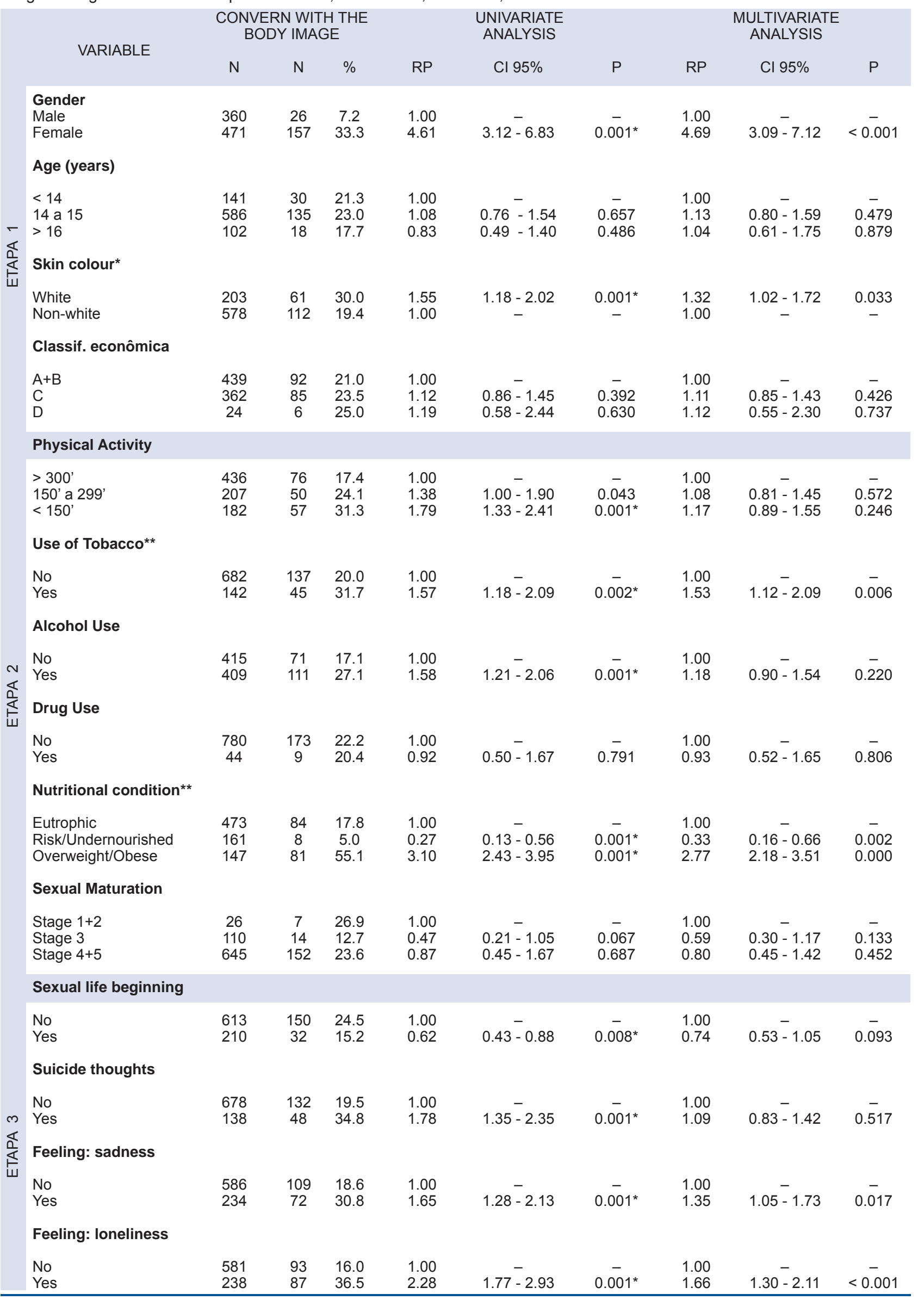

Note. The totals do not coincide with each other due to the lack of information in some cases.

* Variables selected for the second stage of the regression.

** Variables selected for the third stage of the regression. 
authors found significant differences between the genders, like another study ${ }^{24}$, which referred to increasing dissatisfaction directly proportional to the increase of age in females. In males, this trend decreases with the desire for a more athletic torso and a search for weight gain.

It was found in this study that those adolescents who self-reported as white were more concerned with their body image than non-whites. In Gravataí, young people who declared themselves as non-white also showed less dissatisfaction than whites, but this difference was not statistically significant. ${ }^{23}$ However, another study on the same sample, investigating girls exclusively, found that non-whites were significantly more satisfied with their bodies. Similarly, studies of adolescent girls in Trinidad ${ }^{25}$ and South Africa ${ }^{26}$ found less dissatisfaction and fewer eating disorders among black and brown women compared to white women. A study of South African mothers and daughters ${ }^{27}$ comparing the association between body image and BMI between ethnic groups (white, multi-ethnic and black) showed ethnic and cultural differences in attitudinal body image: both mother and daughter non-whites proved less demanding in relation to body image. These results may indicate different standards of beauty depending on the skin colour of individuals, with white people demonstrating reduced satisfaction and greater demands in terms of their body image.

Tobacco experience was also associated with the outcome. Violation of dietary restriction, linking eating disorders and tobacco use, can affect the behaviour of individuals, especially women ${ }^{28}$. One study found that women use tobacco as compensation behaviour, showing dissatisfaction with their image and few healthy nutritional practices. Fear of weight gain can be a major barrier to stopping smoking ${ }^{29}$. This should be considered with women especially, because the possibility of weight gain can demotivate them to stop smoking ${ }^{30}$. Depending on the design used in this study, it is not possible to know whether those most dissatisfied with body image began smoking as a result of this concern or if experience with tobacco came first; however, it can be said that the most concerned young people are also those who have used tobacco.

The prevalence of underweight was higher than that of overweight/obesity. This is interesting and indicates the time of the nutritional transition, given that the north generally, as in other regions, shows a higher prevalence of overweight/obesity. The accelerated decline in malnutrition of children and adults and the increased prevalence of overweight and obesity constitutes a nutritional transition framework in many countries and also in Brazil, due to changes in diet and lifestyle ${ }^{31}$.

In this study, young overweight/obese people were nearly three times more concerned about their body image and those of low weight were less concerned than the eutrophic. These findings are consistent with studies of Gravataí ${ }^{23}$ and Victory ${ }^{32}$, in which overweight children were also more dissatisfied. This result makes sense in our culture, because prejudice against the overweight or obese can lead to greater dissatisfaction with body image. However, it is interesting to note that five per cent of low weight and 17.8 per cent of normal weight youths also expressed dissatisfaction, indicating that this is only partly explained by the social prejudice. Possibly perfect body patterns internalized by the media have an effect on self-image that is not consistent with a healthy nutritional status. ${ }^{7}$ Dissatisfaction with body image, perfectionism, high BMI, women and low self-esteem are factors associated with high rates of eating disorders found in a study of adolescents between 12 and $15^{33}$.

There was no significant association between sexual maturity and concern with body image. However, there was a tendency that the most concerned were those young people in an early stage of sexual development. It is possible that the small number of students in this category has hampered the detection of a significant association. Most young people find themselves in stages 4 and 5, which, for boys, indicates slowing growth and development similar to adults and, for girls, completion of sexual maturation and great bodily changes. Unlike the present study, in Gravataí, there was high prevalence of satisfaction among pre-pubertal and those in early puberty, suggesting that in the south the young child was not as influenced by adult standards of beauty $^{23}$. The pubertal stage did not correlate with self-esteem or with perceptions related to the body, and BMI was the only predictor of body dissatisfaction for adolescents of both sexes ${ }^{34}$. Boys and girls, at the beginning of high school, who considered themselves to be lagging behind in sexual maturity were at risk of body dissatisfaction ${ }^{35}$.

As for the onset of sexual life, was no statistically significant association in the multivariate analysis. However, a tendency was observed that those who had not initiated a sexual life reported higher dissatisfaction with their body image. Perhaps the lack of satisfaction with their body was a contributing factor to the delay of sexual initiation, because they felt their body image inconsistent with that desired. A recent study of adolescent girls found significant correlations between sexual activity, body image and symptoms of depression. Moreover, body image was a predictor of sexual activity ${ }^{36}$.

In terms of psychosocial characteristics, concern about body image was higher among teenagers who reported feelings of sadness and loneliness. Although the presence of these feelings is quite common in adolescence, it is possible that dissatisfaction with the body aggravates feelings of worthlessness and low self-esteem. The influence of the media can become oppressive in suggesting that a certain kind of beauty is associated with personal success, affecting the quality of life and the health of adolescents regarding the shape of their body. A study of 15 year olds and an accompanying measure held eight years later measured self-esteem, life satisfaction, body image, anxiety, depression and somatic complaints. Young people had significantly better self-esteem than men aged 15-23 years. Women were more satisfied with their life than men at 23 years, although these men had a better body image, less anxiety, less depression and fewer somatic complaints, regardless of age $^{37}$.

\section{CONCLUSIONS}

In this study, female students showed greater dissatisfaction with body image, as did those who self-report- 
ed as white and overweight/obese. Those who were underweight were more satisfied than the eutrophic. It is possible that dissatisfaction with body image makes young people more vulnerable to adolescent tobacco use and this discontent is expressed in the higher prevalence of feelings of sadness and loneliness. However, it is certain that a study of cross-sectional design does not allow identification of what is cause and what is consequence. In addition, the exclusion of young people outside the school environment limits the extrapolation of the results to the entire population of adolescents.

Despite these limitations, the results are important for the youth of northern Brazil, since there is little research on this topic in the region. The data serve as a warning to parents, educators and health professionals about the need to develop strategies to promote greater satisfaction and self-confidence in young people and hence greater satisfaction with body image.

At school, the discipline of physical education is closely linked with corporeality, providing opportunities to identify more students dissatisfied with their bodies, especially girls, non-white young and the overweight. It is in this space that they can be offered advice on healthier lifestyles and allied health services, with investment in the planning of actions aimed at promoting healthy environments to improve the quality of life of students. In this sense, it is essential that family support, along with educators, health professionals and the community, enhances the positive qualities of the young, encouraging physical activity and the adoption of habits promoting health holistically.

\section{REFERENCES}

1. Masset KVSB, Safons MP. Excesso de peso e insatisfação com a imagem corporal em mulheres. Arq Sanny Pesq Saúde. 2008;1(1):38-48.

2. Graup S, Pereira EF, Lopes AS, Araújo VC, Legnani RFS, Borgatto AF. Associação entre a percepção da imagem corporal e indicadores antropométricos de escolares. Rev Bras Educ Fís Esp. 2008;22(2):129-38. DOI: http://dx.doi.org/10.1590/S1807-55092008000200004

3. Petroski EL, Pelegrini A, Glaner MF. Motivos e prevalência de insatisfação com a imagem corporal em adolescentes. Cien Saúde Coletiva. 2012;17(4):1071-7.

4. Leite ACB, Ferrazzi NB, Mezadri T, Höfelmann DA. Body dissatisfaction among students in brazilian southern city. J Hum Growth Dev. 2014;24(1):54-61. DOI: http://dx.doi.org/10.7322/jhgd.72154

5. Conti MA. Os aspectos que compõem o conceito de imagem corporal pela ótica do adolescente. Rev Bras Crescimento Desenvolvimento Hum. 2008;18(3);240-53. DOI: http://dx.doi.org/10.7322/jhgd.19887

6. El Ansari W, Dibba E, Stock C. Body Image concerns: levels, correlates and gender differences among students in the United Kingdom. Cent Eur J Public Health. 2014;22(2):106-17. DOI: http://dx.doi.org/10.21101/ cejph.a3944

7. Silva MLA, Taquette SR, Coutinho ESF. Senses of body image in adolescents in elementary school. Rev Saúde Pública. 2014; 48(3):438-44. DOI: http://dx.doi.org/10.1590/S0034-8910.2014048005083

8. Motta-Gallo S, Gallo P, Cuenca A. The influence of television on the eating habits of brazilian northeast children. J Hum Growth Dev. 2013;23(1):87-93. DOI: http://dx.doi.org/10.7322/jhgd.50396

9. Yager Z, O'Dea JA. Relationships between body image, nutritional supplement use, and towards doping in Sport among adolescent boys: implications for prevention programs. J Int Soc Sports Nutr. 2014;11:13. DOI: http://dx.doi.org/10.1186/1550-2783-11-13

10. Malta DC, Andreazzi MAR, Oliveira-Campos M, Andrade SS, Sá NN, Moura L, et al. Trend of the risk and protective factors of chronic diseases in adolescents, National Adolescent School-based Health Survey (PeNSE 2009 e 2012). Rev Bras Epidemiol. 2014;17(1):77-91. DOI: http://dx.doi.org/10.1590/18094503201400050007

11. Instituto Brasileiro de Geografia e Estatística (IBGE). Sinopse do Senso Demográfico de 2014. [cited 2015 July 23] Available from: http://cidades.ibge.gov.br/xtras/perfil.php?codmun=110020.

12. Conti MA, Cordas TA, Latorre MR. Estudo de validade e confiabilidade da versão brasileira do Body Shape Questionnaire (BSQ) para adolescentes. Rev Bras Saúde Mater Infant. 2009;9(3):331-8. DOI: http:// dx.doi.org/10.1590/S1519-38292009000300012

13. Tanner JM. a history of the study of human growth. Cambridge: Cambridge University Press; 1981; p. 397402.

14. Matsudo SM, Araujo T, Matsudo V. Questionário Internacional de Atividade Física IPAQ: estudo de validade e reprodutibilidade no Brasil. Rev Bras Ativ Fís Saúde. 2001;6(2):5-18. DOI: http://dx.doi.org/10.12820/ rbafs.v.6n2p5-18

15. Associação Brasileira de Empresas de Pesquisa (ABEP). Critério de classificação econômica Brasil. [cited 2009 Dec 15] Available from: http://www.abep.org/codigosguias/ABEP_CCEB.pdf

16. Organização Mundial da Saúde (WHO). Global School-based Student Health Survey (GSHS). [cited 2009 Jun 06] Available from: http://www.who.int/chp/gshs/en

17. Organização Mundial da Saúde (WHO). Global School-based Student Health Survey (GSHS) purpose and methodology. [cited 2009 Dec 13] Available from: http://www.who.int/chp/gshs/methodology/index.html

18. Must A, Dallal GE, Dietz WH. Reference data for obesity: 85th and 95th percentiles of body mass index (wt/ht2) and triceps skinfold thickness. Am J Clin Nutr. 1991; 53(4):839-4. 
19. Brasil. Ministério da Saúde. Conselho Nacional de Saúde. Comissão Nacional de Ética em Pesquisa. Resolução n 196, de 10 de outubro de 1996. Brasília: Ministério da Saúde; 1996.

20. Associação Médica Mundial. Declaração de Helsinki. Aprovada na $18^{a}$ Assembléia Médica Mundial, Helsinki, Finlândia 1964 [cited 2009 July 03] Available from: http://www.ufrgs.br/bioetica/helsin1.htm

21. Fidelix YL, Silva DAS, Pelegrini A, Silva AF, Petroski EL. Insatisfação com a imagem corporal em adolescentes de uma cidade de pequeno porte: associação com sexo, idade e zona de domicilio. Rev Bras Cineantropom Desempenho Hum. 2011; 13(3):202-7. http://dx.doi.org/10.5007/1980-0037.2011v13n3p202

22. Pelegrini A, Petroski EL. The association between body dissatisfaction and nutritional status in adolescents. Hum Mov. 2010;11(1):51-7.

23. Aerts D, Madeira RR, Zart VB. Imagem corporal de adolescentes escolares em Gravataí-RS. Epidemiol Serv Saúde. 2010;19(3):283-91. DOI: http://dx.doi.org/10.5123/S1679-49742010000300010

24. Vilela JE, Lamounier JA, Filho MA, Barros NJ, Horta GM. Transtornos alimentares em escolares. J Pediatr. 2004;80(1):49-54. DOI: http://dx.doi.org/10.2223/JPED.1133

25. Ramberan K, Austin M, Nichols SE. Ethnicity, body image perception and weight-related behaviour among adolescent females attending secondary school in Trinidad. West Indian Med J. 2006;55(6):388-93. DOI: http://dx.doi.org/10.1590/S0043-31442006000600004

26. Caradas AA, Lambert EV, Charlton KE. An ethnic comparison of eating attitudes and associated body image concerns in adolescent South African schoolgirls. J Hum Nutr Diet. 2001;14(2):111-20.

27. Mciza Z, Goedecke J, Steyn NP, Charlton KE, Puoane T, Meltzer S, et al. Development and validation of instruments measuring body image and body weight dissatisfaction in South African mothers and their daughters. Public Health Nutr. 2005; 8(5):509-19. DOI: http://dx.doi.org/10.1079/PHN2005814

28. Kovacs MA, Correa JB, Brandon TH. Smoking as alternative to eating among restrained eaters: effect of food prime on young adult female smokers. Health Psychol. 2014;33(10):1174-84. DOI: http://dx.doi. org/10.1037/hea0000123

29. Nerín I, Beamonte A, Gargallo P, Jiménez MA, Marqueta A. Weight Gain and Anxiety Levels in Recent ExSmokers. Arch Bronconeumol. 2007;43(1):9-15. DOI: http://dx.doi.org/10.1016/S1579-2129(07)60014-7

30. Nunes E. Consumo de tabaco. Efeitos na saúde. Rev Port Clin Ger. 2006;22:225-44.

31. Soares LR, Pereira MLC, Mota MA, Jacob TA, Silva VYNE, Kashiwabara TGB. A transição da desnutrição para a obesidade. Braz J Surg Clin Res. 2014;5(1):64-8.

32. Braga PD, Molina MCB, Cade NV. Expectativas de adolescentes em relação a mudanças do perfil nutricional. Cien Saúde Coletiva. 2007;12(5):1221-8. DOI: http://dx.doi.org/10.1590/S1413-81232007000500019

33. Gutiérrez T, Espinoza P, Penelo E, Mora M, González ML, Rosés R, et al. Association of biological, psychological and lifestyle risk factors for eating disturbances in adolescents. J Health Psychol. 2015;20(6):83949. DOI: http://dx.doi.org/10.1177/1359105315577302

34. Altıntas A, Asç FH, Kin-İsler A, Güven-Karahan B, Kelecek S, Özkan A, et al. The role of physical activity, body mass index and maturity status in body-related perceptions and self-esteem of adolescents. Ann Hum Biol. 2014;41(5):395-402. DOI: http://dx.doi.org/10.3109/03014460.2013.857721.

35. Guzman NS, Nishina A. A longitudinal study of body dissatisfaction and pubertal timing in an ethnically diverse adolescent sample. Body Image. 2014;11(1):68-71. DOI: http://dx.doi.org/10.1016/j.bodyim.2013.11.001

36. Anatale K, Kelly S. Factors influencing adolescent girls' sexual behavior: a secondary analysis of the 2011 youth risk behavior survey. Issues Ment Health Nurs. 2015;36(3):217-21. DOI: http://dx.doi.org/10.3109/0 1612840.2014.963902

37. Gestsdottir S, Arnarsson A, Magnusson K, Arngrimsson SA, Sveinsson T, Johannsson E. Gender differences in development of mental well-being from adolescence to young adulthood: an eight-year follow-up study. Scand J Public Health. 2015;43(3):269-75. DOI: http://dx.doi.org/10.1177/1403494815569864

This article is distributed under the terms of the Creative Commons Attribution 4.0 International License (http://creativecommons.org/licenses/by/4.0/), which permits unrestricted use, distribution, and reproduction in any medium, provided you give appropriate credit to the original author(s) and the source, provide a link to the Creative Commons license, and indicate if changes were made. The Creative Commons Public Domain Dedication waiver (http://creativecommons.org/publicdomain/zero/1.0/) applies to the data made available in this article, unless otherwise stated. 


\section{Resumo:}

Introdução: Enquanto evidências sugerem que níveis de coordenação motora e de índice de massa corporal (IMC) estão negativamente correlacionados, pouco se sabe sobre a influência dos níveis de atividade física na associação entre essas variáveis em adolescentes.

Objetivo: Analisar as associações entre os níveis de coordenação motora e o IMC em adolescentes com peso saudável e com sobrepeso/obesos, controlando pelos níveis de atividade física.

Método: Cinquenta e seis escolares (50\% adolescentes com sobrepeso/obesos), entre 12 e 14 anos, participaram do estudo. Os instrumentos Physical Activity Questionnaire for Older Children e o Körperkoordinationstest für Kinder foram usados para avaliar os níveis de atividade física e de coordenação motora, respectivamente. Correlações bivariadas e parciais foram usadas para analisar o interrelacionamento entre os níveis de coordenação motora, IMC e atividade física. O teste de Análise de Covariância foi utilizado para comparar os níveis de coordenação entre adolescentes com peso saudável e com sobrepeso/obesos, considerando o nível de atividade física como covariável.

Resultados: Foram encontradas correlações significativamente negativas $(p<0,05)$, de fraca a moderada, entre IMC e níveis de coordenação no grupo como um todo, nos grupos com peso saudável e com sobrepeso/obesos. No entanto, quando controladas pelos níveis de atividade física, não foram observadas correlações significativas no grupo com peso saudável. Ademais, adolescentes com sobrepeso/obesos apresentaram menores níveis de coordenação motora que adolescentes com peso saudável.

Conclusão: Os níveis de atividade física influenciam a associação entre os níveis de coordenação motora e IMC em adolescentes com peso saudável, mas não em adolescentes com sobrepeso/obesos.

Palavras-chave: adolescente, atividade motora, sobrepeso, obesidade. 